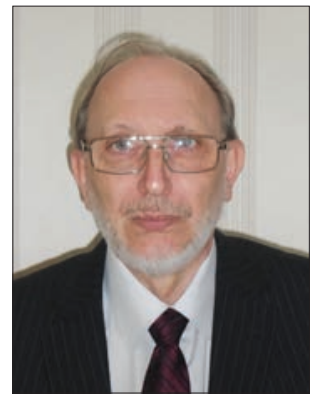

Aleksandr A. Yepifanov

Епифанов

Александр

Анатольевич

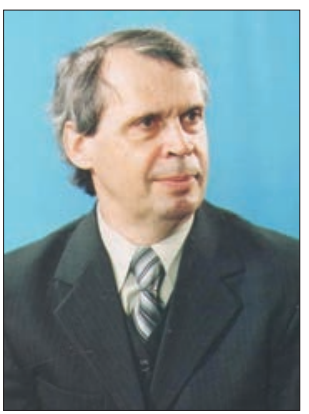

Boris V. Dymo

Дымо Борис

Васильевич

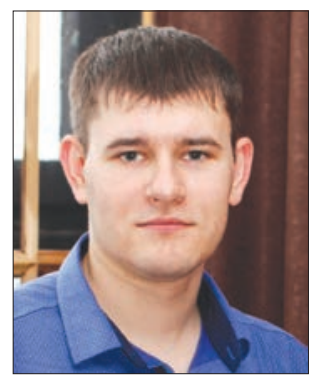

Pavel A.

Patsurkovskyi

Пацурковский

Павел

Анатольевич

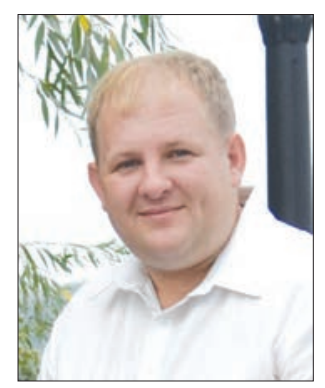

Andrii V.

Yazlovetskyi

Язловецкий

Андрей

Валерьевич

УДК 662.995:662.61

\title{
INFLUENCE OF FLUE GASES RECIRCULATION ON TECHNICAL AND ECOLOGICAL INDICATORS OF SHIP AUXILIARY BOILER PERFORMANCE
}

\section{ВЛИЯНИЕ РЕЦИРКУЛЯЦИИ ДЫМОВЫХ ГАЗОВ НА ТЕХНИЧЕСКИЕ И ЭКОЛОГИЧЕСКИЕ ПОКАЗАТЕЛИ РАБОТЫ СУДОВОГО ВСПОМОГАТЕЛЬНОГО КОТЛА}

DOI https://doi.org/10.15589/smi2020.2(14).1

\author{
Aleksandr A. Yepifanov Епифанов Александр Анатольевич, \\ канд. техн. наук, доц. \\ epifanov.nuk@gmail.com \\ ORCID: 0000-0001-8744-4779
}

Boris V. Dymo

Дымо Борис Васильевич, канд. техн. наук, проф. dymobv@gmail.com

ORCID: 0000-0001-5162-4559

Pavel A. Patsurkovskyi Пацурковский Павел Анатольевич, канд. техн. наук, ассистент pavlo.patsurkovskyi@nuos.edu.ua ORCID: 0000-0003-1120-5362

Andrii V. Yazlovetskyi
Язловецкий Андрей Валерьевич, ассистент andrei.yaz83@gmail.com
ORCID: 0000-0002-2711-3692

\section{Admiral Makarov National University of Shipbuilding, Mykolayiv \\ Национальный университет кораблестроения имени адмирала Макарова, 2. Николаев}

Abstract. The main methods of reducing nitrogen oxides concentration in flue gases during the boiler plants operation are considered and analyzed. It was shown that simplified recirculation scheme with the flue gases supply into the inlet of the blower fan makes it possible to reduce emissions of nitrogen oxides at relatively low capital and operating costs. The aim of the work is to evaluate the impact of flue gases recirculation into the furnace on the technical, economic and ecological characteristics of the ship's auxiliary boiler. The research was carried out using the methods of computer simulation. A new data of the flue gases recirculation effect on the main characteristics of the ship auxiliary boiler Aalborg OM-TCi with a steam capacity of 20,0 $\mathrm{t} / \mathrm{h}$ were obtained. It was found that the recirculation of flue gases in the range of $0 \ldots 20 \%$ leads to a decrease in the adiabatic temperature in the furnace by $273^{\circ} \mathrm{C}$ (from 1919 to $1646^{\circ} \mathrm{C}$ ), the average integral temperature in the active combustion zone decrease from 1773 to $1534^{\circ} \mathrm{C}$, and the temperature of gases at the outlet of the furnace decrease from 1300 to $1233^{\circ} \mathrm{C}$. The boiler flue gas temperature rises from 225 to $236^{\circ} \mathrm{C}$. An increase in heat losses with flue gases by $0,5 \%$ leads to a decrease of the boiler efficiency from 89,2 to $88,7 \%$. The furnace heat absorption decreases by $999 \mathrm{~kW}$ and the heat absorption of convective steam-generating tube bundle increases by $900 \mathrm{~kW}$. The decrease in the boiler steam output is $0,11 \mathrm{t} / \mathrm{h}$. The recirculation coefficient in the range of $10 \ldots 15 \%$ is recommended to choose on the basis of the study results. The given values of the recirculation coefficient correspond to an increase in the resistance of the gas-air path of the boiler by $25 \%$, as well as a decrease in nitrogen oxide emissions by $44 \%$.

Key words: ship auxiliary boiler, flue gases recirculation, nitrogen oxide emissions, fuel combustion, reduction of harmful emissions. 
Анотація. У роботі розглянуто та проаналізовано основні методи зниження концентрації оксидів азоту в димових газах під час експлуатації котельних установок. Для суднових котлів рекомендовано метод рециркуляції з подачею димових газів на вхід дуттєвого вентилятора за спрощеною схемою, який дає змогу знижувати викиди оксидів азоту за порівняно низьких капітальних та експлуатаційних витрат. Метою роботи є дослідження впливу рециркуляції димових газів на техніко-економічні й екологічні характеристики суднового допоміжного котла. Дослідження проводилося із застосуванням методу математичного моделювання. Отримано нові дані про вплив рециркуляції димових газів на основні характеристики роботи суднового допоміжного котла типу Ольборг ОМ ТСі з паропродуктивністю 20,0 т/год. Встановлено, що зі збільшенням коефіцієнта рециркуляції в діапазоні від 0 до $20 \%$ адіабатна температура в топці знижується на $273^{\circ} \mathrm{C}\left(31919^{\circ} \mathrm{C}\right.$ до $\left.1646^{\circ} \mathrm{C}\right)$, середньоінтегральна температура в зоні активного горіння знижується на $239^{\circ} \mathrm{C}\left(31773^{\circ} \mathrm{C}\right.$ до $\left.1534^{\circ} \mathrm{C}\right)$, а температура газів на виході з топки знижується на $67^{\circ} \mathrm{C}\left(31300^{\circ} \mathrm{C}\right.$ до $\left.1233^{\circ} \mathrm{C}\right)$. При цьому температура відхідних газів підвищується на $11^{\circ} \mathrm{C}\left(3225^{\circ} \mathrm{C}\right.$ до $\left.236^{\circ} \mathrm{C}\right)$. Зростання втрат теплоти з газами призводить до зменшення коефіцієнта корисної дії котла в діапазоні з 89,2\% до 88,7\%. Теплова потужність топки зменшується на 999 кВт (з 5339 до 4340 кВт), а конвективного паротвірного пучка зростає на 920 кВт (з 8557 до 9477 кВт). Паропродуктивність котла зменшується з 5,56 до 5,53 кг/с. На основі результатів проведених досліджень рекомендується вибирати коефіцієнт рециркуляції в діапазоні від 10 до 15\%. За таких значень коефіцієнта рециркуляції димових газів опір газоповітряного тракту котла підвищується з 11,7 до 24,8\%, а викиди оксидів азоту знижуються з 32,5 до 43,9\%.

Ключові слова: судновий допоміжний котел, рециркуляція димових газів, викиди оксидів азоту, спалювання палива, зниження шкідливих викидів.

Аннотация. Рассмотрены и проанализированы основные методы снижения концентрации оксидов азота в дымовых газах при эксплуатации котельных установок. Рекомендован для судовых котлов метод рециркуляции с подачей дымовых газов на вход дутьевого вентилятора, что позволяет снижать выбросы оксидов азота при сравнительно низких капитальных и эксплуатационных затратах. Целью работы является исследование влияния рециркуляции дымовых газов на технические характеристики судового вспомогательного котла. Исследование проводилось с применением метода математического моделирования. Получены новые данные о влиянии рециркуляции дымовых газов на основные характеристики работы судового вспомогательного котла типа Ольборг ОМ ТСі паропроизводительностью 20,0 т/ч. Установлено, что с увеличением коэффициента рециркуляции в диапазоне 0-20\% адиабатная температура в топке снижается с $1919^{\circ} \mathrm{C}$ до $1646^{\circ} \mathrm{C}$, среднеинтегральная температура в зоне активного горения - с $1773^{\circ} \mathrm{C}$ до $1534^{\circ} \mathrm{C}$, а температуры газов на выходе из топки - от 1300 до $1233^{\circ} \mathrm{C}$. При этом температура уходящих газов повышается с $225^{\circ} \mathrm{C}$ до $236^{\circ} \mathrm{C}$. Рост потерь теплоты с уходящими газами приводит к уменьшению коэффициента полезного действия котла в диапазоне $89,2-88,7 \%$. Тепловая мощность топки уменьшается с 5339 до 4340 кВт, а конвективного парообразующего пучка возрастает с 8557 до 9477 кВт. Паропроизводительность котла уменьшается с 5,56 до 5,53 кг/с. На основе результатов проведенных исследований рекомендуется выбирать коэффициент рециркуляции в диапазоне $10-15 \%$. При таких значених коэффициента рециркуляции сопротивление газовоздушного тракта котла повышается на 11,7-24,8\%, а выбросы оксидов азота снижаются на 32,5-43,9\%.

Ключевые слова: судовой вспомогательный котел, рециркуляция дымовых газов, выбросы оксидов азота, сжигание топлива, снижение вредных выбросов.

\section{References}

[1] Aerodinamicheskiy raschet kotelnikh ustanovok (1977). L., Energiya. 255 p. (in Russian).

[2] Epifanov, O.A. (2004). Teploviy rozrakhunok kotelnikh agregativ maloi potuzhnosti. Mikolajiv: NUK. 152 p. (in Ukrainian).

[3] Epifanov, O.A. (2016). Konstruktsii sudnovikh kotliv. Navchalniy posibnik. (Yelektronne vidannya kombinovanogo vikoristannya na DVD-ROM). Mikolajiv, NUK. 198 p. (in Ukrainian).

[4] Kabishov, S.M. et. al. (2013). Analiz effektivnosti tekhnologicheskikh metodovo snizheniya vybrosov $\mathrm{NO}_{\mathrm{x}}$ pri szhiganii uglevodorodnogo topliva $\mathrm{v}$ teploenerge-ticheskikh ustanovkakh. Energetika. Izvestiya vysshikh uchebnykh zavedeniy i energeticheskikh obedineniy $S N G$, no. 2, pp. 48-53. (in Russian). 
[5] Kanygin, A.V. (2013). O sovremennykh metodakh snizheniya obrazovaniya oksidov azota pri szhiganii gaza v kotlakh maloy i sredney moshchnosti. Promyshlennaya teplotekhnika, no. 2, pp. 79-86. (in Russian).

[6] Kobzar, S.G. (2009). Snizhenie vybrosov oksidov azota v gazovykh kotlakh metodom retsirkulyatsii dymovykh gazov. Promyshlennaya teplotekhnika, no. 4, pp. 5-11. (in Russian).

[7] Mikhaylov, A.G. (2013). Razrabotka teoreticheski osnov snizheniya obrazovaniya oksidov azota v topkakh gazotrubnykh kotlov Nauchnyy zhurnal KubGAU, no. 90 (06). (in Russian).

[8] Parchevskiy, V.M. (2010). Upravlenie vybrosami oksidov azota na TES retsirku-lyatsiey dymovykh gazov: dis. ... kand. tekhn. nauk: 05.13.06. Moskva. 199 p. (in Russian).

[9] Prilozhenie VI k MARPOL 73/78. Pravila predotvrashcheniya zagryazneniya atmosfery s sudov/ Retrieved from: http://www.morkniga.ru.

[10] RD 153-34.02.304-2003. (2003). Metodicheskie ukazaniya po raschetu vybrosov oksidov azota s dymovymi gazami kotlov teplovykh elektrostantsiy. M., OAO «VTI». 42 p. (in Russian).

[11] Sigal, I.Ya. (2018). Osobennosti vliyaniya retsirkulyatsii produktov sgoraniya na obrazovanie oksidov azota v kotlakh pri szhiganii prirodnogo gaza. Energotekhnologi i resursosberezhenie, no.4. pp. 62-66. (in Russian).

[12] Taymarov, M.A., Chiklyaev, D.E. (2013). Obrazovanie termicheskikh okislov azota pri szhiganii gaza. Vestn. Kazan. Tekhnol. un-ta, T. 16, no. 23, pp. 73-75. (in Russian).

[13] Teplovoy raschet kotlov (normativnyy metod). (1998). 3-e izd., pererabotan-noe i dopolnennoe. SPb, Izd-vo NPO TsKTI. 256 p. (in Russian).

[14] Timofeev, O.Ya., Valdman, N.A., Kryzhevich, M.I. (2014). Osobennosti vnedreniya novykh trebovaniy k ekologicheskoy bezopasnosti sudov i morskikh ustanovok v severnykh moryakh i na arkticheskom shelfe. Arktika: ekologiya i ekonomika, no. 3 (15), pp. 79-85. (in Russian).

[15] Khryapchenkov, A.S. (1988). Sudovye vspomogatelnye i utilizatsionnye kot-ly. 2-e izd., pererab. i dop. Leningrad, Sudostroenie. 296 p. (in Russian).

[16] Fedorenko, V.M., Zaletov, V.M., Rudenko, V.I., Belyaev, I.G. (1991). Ekspluatatsiya sudovykh kotelnykh ustanovok. M., Transport. 272 p. (in Russian).

[17] Alfa Laval Aalborg Industries. Retrieved from: http://www.aalborg-industries.com/marine boilers.

[18] SAACKE GmbH. Retrieved from: http://www.saacke.com/products/marine-boilers.

[19] V. Ganapathy. (2015). Steam Generators and Waste Heat Boilers: For Process and Plant Engineers. Taylor \& Francis Group, LLC. 495 p.

[20] Reduction of $\mathrm{SO}_{2}, \mathrm{NO}_{\mathrm{x}}$ and Particulate Matter from Ships with Diesel Engines. (2014). Environmental Project. no. 1510.114 p. Retrieved from: https://www2.mst.dk/Udgiv/ publications/2014/03/978-87-93026-57-5.pdf.

Постановка проблемы. В настоящее время со стороны Международной морской организация (IMO) значительно возросли требования к выбросу в составе отработавших газов судовых энергетических установок (СЭУ) различных токсических веществ: $\mathrm{NO}_{\mathrm{x}}, \mathrm{SO}_{2}, \mathrm{CO}, \mathrm{C}_{\mathrm{n}} \mathrm{H}_{\mathrm{m}}, \mathrm{CO}_{2}$ и др. Наиболее экологически опасные из них - выбросы оксидов азота и серы с отработавшими газами дизелей и котлов морских судов - нормируются Приложением VI «Предотвращение загрязнения атмосферы с судов» к Международной конвенцией MARPOL 73/78, вступившим в силу с 19 мая 2005 года. В настоящее время принята программа поэтапного их снижения. С 1 июля 2010 г. вступила в силу новая редак- ция Приложения VI, предусматривающая более жесткие требования к выбросам [3; 9; 20]. С 1 января 2011 г. IMO ужесточила нормы выбросов оксидов азота на 20\% (уровень Tier II), a с 2016 г. запланировано ужесточение норм в зонах контроля эмиссии оксидов азота ( $\mathrm{NO}_{x}$ Emission Control Area - NECA) на 80\% (уровень Tier III).

Несмотря на то, что вклад СЭУ в глобальное загрязнение воздушного бассейна оценивается в 2-3\% от общего количества выбрасываемых всеми источниками вредных веществ, в местах интенсивного судоходства и скопления судов - портах, проливах, каналах и пр. - судовые котлы становятся мощными источниками локального 
и регионального загрязнения атмосферы. Указанное требует разработки и внедрения на судах методов снижения выбросов загрязняющих веществ в атмосферу, а также исследования влияния этих методов на технические характеристики судовых котлов.

Анализ последних исследований и публикаций. Анализ литературных данных показал, что большинство работ направлены на мониторинг выбросов загрязняющих веществ от стационарных энергетических установок или передвижных береговых транспортных средств:

- в работах $[4 ; 7 ; 19]$ рассматриваются механизмы образования оксидов азота при сжигании газообразного топлива и мазута, анализируются существующие методы снижения выбросов оксидов азота в атмосферу и обосновывается выбор метода для внедрения;

- в работе [6] показано, что метод рециркуляции дымовых газов имеет лучшее соотношение эффективность - стоимость. Установлено, что оптимальное значение доли рециркуляции для промышленного котла ДКВр-4/13 с горелками ГМГ-2 при сжигании газообразного топлива находится в области 15-20\%. При этом обеспечивается снижение эмиссии оксидов азота на 50-70\% при увеличении давления на прокачку дутьевой смеси на 20-30\%;

- результаты расчетов интенсивности образования окислов азота при работе котла ПК-47 на природном и пиролизном газах и степени рециркуляции 0,1 показали, что наиболее сильно образование термических окислов азота зависит от теплоты сгорания топлива; при снижении значений избытка воздуха в газах рециркуляции и температуры газов на выходе из топки образование окислов азота замедляется [12];

- в работе [4] внимание уделено исследованию снижения выбросов $\mathrm{NO}_{\text {x }}$ при сжигании углеводородного топлива воздухом, обогащенным кислородом. Выполненные расчеты показали, что при обогащении до 50\% кислородом удается снизить объем образования $\mathrm{NO}_{\text {на }} 21 \%$;

- в результате исследований в работе [5] выполнен сравнительный анализ техникоэкономических и экологических характери- стик водотрубно-дымогарного котла тепловой мощностью 630 кВт, полученных при моделировании в программном комплексе ANSYS FLUENT. Показано, что размещение трубного пучка в топке создает условия для интенсификации конвективного топочного теплообмена, дополнительного охлаждения газов в зонах рециркуляции, снижение температуры в топке и уменьшения концентрации $\mathrm{NO}_{\mathrm{x}}$;

- в диссертации [8] разработана расчетно-экспериментальная методика определения эколого-экономических характеристик стационарных газомазутных котлов при использовании рециркуляции дымовых газов;

- в статье [11] показано, что при подаче в виде балласта газов рециркуляции необходимо учитывать содержание в них оксидов азота. Рекомендуется в качестве балласта, снижающего образование оксидов азота при горении, использовать диоксид углерода.

В области СЭУ основное внимание уделяется снижению выбросов оксидов азота $\mathrm{NO}_{\text {x }}$ главными ДВС с целью выполнения норм уровней Tier II и Tier III [20]. В статье [14] рассматриваются особенности внедрения новых международных требований к экологической безопасности морских судов на континентальном шельфе Арктики и на Северном морском пути. Выполнен анализ возможных вариантов использования на судах оборудования, обеспечивающего современные требования к защите атмосферного воздуха. Указанв перспективность применения сжиженного природного газа в качестве топлива для судовых дизелей и котлов.

Выделение не решенных ранее частей общей проблемы. В литературе практически отсутствуют данные по выбросам окислов азота судовыми котельными установками, использованию методов борьбы с ними и влиянию этих методов на технические характеристики судовых котлов. В пособии [16] указываются такие цифры: вспомогательный котел типа КАВ паропроизводительностью 0,28 кг/с, работающий на мазуте, выбрасывает в атмосферу 4 кг $\mathrm{SO}_{2}$ и 2,25 кг $\mathrm{NO}_{\text {х }}$ в час. Эти выбросы, отнесенные к $1 \mathrm{~m}^{3}$ дымовых газов при нормальных физических условиях, составляют соответственно 


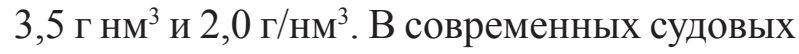
котлах фирмы «Сааке» (Германия) выбросы $\mathrm{NO}_{\mathrm{x}}$ не превышают 0,8 г/ $\mathrm{M}^{3}$ при сжигании тяжелых сортов жидкого топлива. В экологических котлах типа FMB-VF-LONOX фирмы «Сааке» за счет рециркуляции дымовых газов в топку эти выбросы снижены

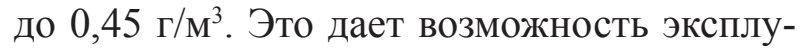
атировать такие котлы в любом порту мира [3; 18]. В то же время отсутствуют данные по влиянию рециркуляции газов на технические и экологические показатели работы судовых вспомогательных котлов.

Цель исследования заключается в оценке влияния на технико-экономические и экологические характеристики судовых вспомогательных котлов рециркуляции дымовых газов в топку для снижения выброса оксидов азота в атмосферу.

Методы, объект и предмет исследования. Метод исследования - математическое моделирование и сравнение его результатов с литературными экспериментальными данными.

Объект исследования - процесс рециркуляции дымовых газов в топку судового вспомогательного котла.

Предмет исследования - параметры процессов горения, теплообмена, газодинамики и образования оксидов азота в судовом вспомогательном котле с рециркуляцией дымовых газов в топку.

Основной материал. В топках котлов при горении топлива образуются оксиды азота двух типов - оксид NO и диоксид $\mathrm{NO}_{2}$, причем на выходе из дымовых труб оксид NO составляет до 95\% суммы оксидов $\mathrm{NO}_{\mathrm{x}}=\mathrm{NO}+\mathrm{NO}_{2}$. Доокисление $\mathrm{NO}$ до $\mathrm{NO}_{2}$ происходит в атмосфере в процессе распространения дымового факела свободным кислородом (озоном) воздуха. Поэтому массовый выброс оксидов азота из котлов рассчитывается по $\mathrm{NO}_{2}$. В газовых выбросах тепловых электростанций их концентрация

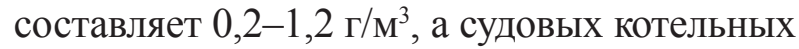
установок может достигать 2 г/м ${ }^{3}$ и более.

Оксиды азота образуются при сгорании топлива в ядре факела тремя возможными путями: топливные образуются при температуре газовой среды 800-2100 К за счет азо- та, входящего в топливо $\left(\mathrm{N}^{\mathrm{p}}\right)$; термические образуются при высоких температурах факела (более $1600 \mathrm{~K}$ ) за счет окисления азота воздуха; быстрые образуются при контакте промежуточных углеводородных соединений топлива (при сжигании газа и мазута) с азотом поступающего в горелки воздуха в начальной зоне горения факела при температурах выше 1000 К. Потребность в высоких температурах при образовании термических оксидов азота обусловлена высоким уровнем энергии активации реакции образования NO (E = 314 кДж/моль). Количество термических $\mathrm{NO}_{x}$ становится значительным при температуре факела выше $1600^{\circ} \mathrm{C}[6 ; 12 ; 16]$.

Содержание оксидов азота в уходящих из котлов газах зависит от конструкции топки, длины, температуры и интенсивности факела, качества топлива (содержания в нем азота, теплотворной способности), избыточной подачи воздуха на процесс горения, времени нахождения газообразных продуктов сгорания в зоне высоких температур и местных температурных пиков.

В настоящее время существуют два подхода к уменьшению концентрации $\mathrm{NO}_{x}$ в дымовых газах: первичные методы, заключающиеся в подавлении образования $\mathrm{NO}_{x}$ в топках котлов, и вторичные, заключающиеся в обработке дымовых газов после котла. К первичным относятся следующие методы: дожигания, стадийной подачи воздуха, модернизации горелок, впрыска воды или пара в топку котла, технология кипящего слоя, сжигания с малыми избытками воздуха, рециркуляции дымовых газов. Селективное некаталитическое и селективное каталитическое восстановления представляют группу вторичных методов.

Метод дожигания топлива - один из эффективных первичных методов снижения эмиссии $\mathrm{NO}_{x}$. Идея этого метода состоит в разделении расхода топлива на две части, а расхода окислителя - не менее чем на две части. На предварительном этапе происходит сжигание основной массы топлива с коэффициентом избытка воздуха 1,05-1,2 и выделением около $80 \%$ энергии. На втором этапе в зону дожигания, где формируется зона восстановления, подается остальное 
топливо с коэффициентом избытка воздуха $0,7-0,9$. При сжигании мазута данная технология обеспечивает снижения выбросов $\mathrm{NO}_{\mathrm{x}}$ до $50 \%[4 ; 6]$.

Метод стадийной подачи воздуха заключается в разделении зоны горения на две: богатую и бедную. В первой зоне организуется сжигание топлива с недостатком кислорода (коэффициент избытка воздуха $\alpha=0,8-0,95)$ и большим временем пребывания продуктов реакций. Частично охлажденные продукты неполного горения дожигаются во второй зоне. Время пребывания продуктов горения во второй зоне должно быть значительно меньше, чем в первой. При этом выбросы оксидов азота снижаются примерно на 15-30\% [4; 6].

Модернизация горелок (низкоэмиссионные горелки) направлена на изменение конструкции стандартных горелок с целью организации более длинного факела. Увеличение длины факела затягивает процесс горения и уменьшает пик температуры, что, в свою очередь, дает уменьшение генерации оксидов азота в зоне горения.

Впрыск (инжектирование) воды или пара в факел приводит к снижению температуры пламени и уменьшению образования оксидов азота по термическому механизму. На газомазутных котлах этот метод позволяет снизить

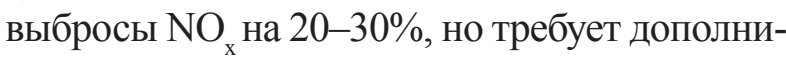
тельных затрат теплоты на парообразование, вызывает увеличение потерь с уходящими газами, снижение КПД котла на 3-10\% и повышение точки росы дымовых газов [4; 6].

При сжигании топлива в низкотемпературном кипящем слое температура в топке относительно невысока и составляет $800-1000^{\circ} \mathrm{C}$, что уменьшает образование термических оксидов азота. Содержание оксидов азота в дымовых газах составляет 100-200 мг/м³ [2].

При сжигании с малыми избытками воздуха в результате снижения содержания кислорода в зоне горения происходит подавление образования как термических, так и топливных $\mathrm{NO}_{x}$. Наряду с экологическим эффектом (снижение выбросов $\mathrm{NO}_{x}$ на 30-40\%) этот метод позволяет повысить КПД котла за счет снижения потерь теплоты с уходящими газами. Уменьшаются также затраты энергии на тяго-дутьевые устройства. При сжигании серосодержащих топлив снижается скорость низкотемпературной коррозии. Однако реализация этого метода требует контроля потери теплоты с недожогом топлива.

Влияние рециркуляции инертной среды (дымовых газов) на выход оксидов азота объясняется снижением максимальной температуры в зоне горения и концентраций реагирующих веществ $\mathrm{O}_{2}$ и $\mathrm{N}_{2}$. Это ведет к уменьшению скорости реакции горения, «растягиванию» зоны горения и вследствие этого - более эффективной теплоотдаче от этой зоны и интенсивному ее охлаждению. Температура дымовых газов, которые подаются на рециркуляцию, влияет на эффективность метода - эффективность повышается с уменьшением температуры газов. Для организации рециркуляции уходящие из котла газы при температуре $200-400^{\circ} \mathrm{C}$ отбираются из дымохода и по специальному трубопроводу подаются на всасывание дутьевого вентилятора (рис. 1). При этом различают три способа ввода газов в топочную камеру: через шлицы под горелками, через кольцевой канал вокруг горелок, подмешивание газов в дутьевой воздух перед горелками. Самым эффективным является последний способ: при коэффициенте рециркуляции 0,15 снижение выбросов $\mathrm{NO}_{\text {х }}$ составляет примерно 50\%. Коэффициент рециркуляции определяется как отношение объема дымовых газов, которые отбираются на рециркуляцию, к объему дымовых газов за местом отбора $[4 ; 6 ; 13]$.

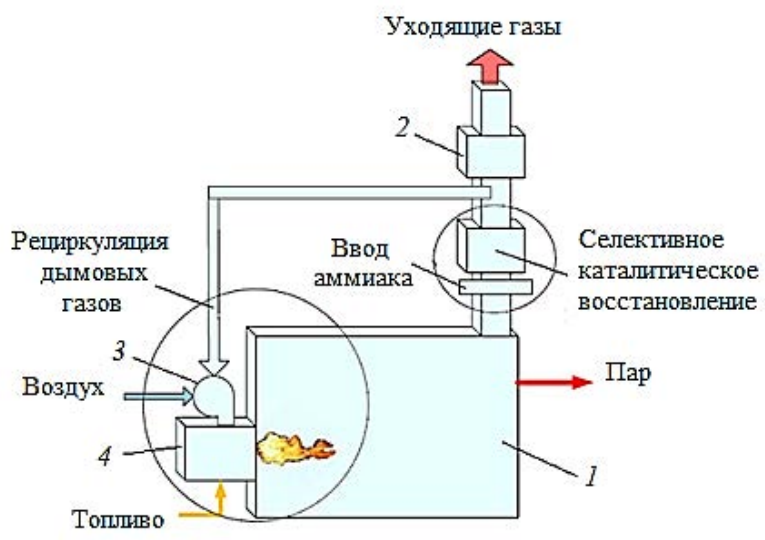

Рис. 1. Методы снижения выбросов $\mathrm{NO}_{\mathrm{x}}: 1$ - котел; 2 - экономайзер; 3 - вентилятор; 4 - топочное устройство 
Следует учитывать, что рециркуляция газов связана с дополнительными затратами на ее организацию: установкой специальных дымососов, монтажом трубопровода рециркуляции, возрастанием мощности дутьевых вентиляторов. Последнее обусловлено увеличением необходимой производительности вентилятора из-за подмешивания к воздуху дымовых газов и более высокой температурой газовоздушной смеси. Кроме того, рециркуляция газов приводит к повышению сопротивления газовоздушного тракта котла.

Вторичные (химические) методы снижения выбросов $\mathrm{NO}_{\text {x }}$ - селективного некаталитического (СНКВ) и селективного каталитического (СКВ) восстановления оксидов азота - связаны с применением систем газоочистки. Первый метод заключается во впрыске реагента (аммиак или мочевина) в дымовые газы котла при температуре газов $750-900^{\circ} \mathrm{C}$. Реагент преобразует содержащийся в дымовых газах $\mathrm{NO}_{\text {х }}$ в молекулярный азот и воду. При реализации второго метода впрыск реагента происходит в присутствии катализатора при меньшей температуре $260-650^{\circ} \mathrm{C}$. Указанные вторичные методы хотя и обеспечивают высокую степень очистки дымовых газов до 90\%, но связаны со значительными затратами и основаны на использовании вредных химических реагентов. По оценкам Института морских исследований Финляндии, увеличение капитальных затрат при применении системы СКВ составляет примерно 50 евро на 1 кВт мощности судовой установки, а эксплуатационных - 5-7 евро. Кроме того, оборудование СКВ массой около 500 т занимает значительный объем, что снижает доходы судовладельцев из-за снижения полезного пространства на судне [14].

Анализ литературных данных показал, что одним из наиболее эффективных и дешевых методов снижения выбросов окси- дов азота является метод рециркуляции дымовых газов (табл. 1). Этот метод находит применение при эксплуатации современных судовых котлах, таких как FMB-VF-LONOX фирмы «Сааке» [18].

Для оценки влияния рециркуляции дымовых газов на технико-экономические и экологические показатели работы судового вспомогательного котла разработана математическая модель, которая позволяет определять:

- адиабатную и среднеинтегральную температуры в зоне активного горения (ЗАГ), температуры на выходе из топки и уходящих из котла газов, а также температуру смешения дутьевого воздуха и газов рециркуляции;

- паропроизводительность котла, тепловосприятие топки и конвективного парообразующего пучка;

- потерю теплоты с уходящими газами и коэффициент полезного действия котла;

- аэродинамическое сопротивление газовоздушного тракта, производительность и мощность дутьевого вентилятора;

- выбросы оксидов азота.

Новизна разработанной математической модели заключается в возможности определения параметров процессов горения, теплообмена, газодинамики и образования оксидов азота в судовом вспомогательном котле с рециркуляцией дымовых газов в топку.

Достоверность результатов расчета обеспечивается удовлетворительным согласованием с литературными экспериментальными данными [6], а также использованием интерполяционных полиномов пятой степени для определения теплоемкости и физических свойств компонентов дымовых газов [13].

Расхождение между тепловыми мощностями конвективной поверхности нагрева из уравнений теплового баланса и теплопередачи принималось не более $2 \%$, а невязка теплового баланса $-0,5 \%$.

Таблица 1. Эффективность методов снижения выбросов $\mathrm{NO}_{\text {x }}$ \% (мазут)

\begin{tabular}{|c|c|c|c|c|}
\hline $\begin{array}{c}\text { Дожигание } \\
\text { топлива }\end{array}$ & $\begin{array}{c}\text { Уменьшение } \\
\text { избытка } \\
\text { воздуха }\end{array}$ & $\begin{array}{c}\text { Стадийная } \\
\text { подача } \\
\text { воздуха }\end{array}$ & $\begin{array}{c}\text { Рециркуляция } \\
\text { дымовых } \\
\text { газов }\end{array}$ & $\begin{array}{c}\text { Впрыск } \\
\text { воды или пара }\end{array}$ \\
\hline 50 & 40 & 30 & 50 & 30 \\
\hline
\end{tabular}


Математическая модель реализована применительно к современному судовому вспомогательному котлу Ольборг ОМ-ТСі фирмы «Альфа Лаваль Ольборг Індастріз». Котел паровой вертикально-цилиндрический газоводотрубный (рис. 2). Паропроизводительность котла на номинальной нагрузке без рециркуляции газов - 20,0 т/ч, а КПД - $89 \%$ [17].

Конвективный парообразующий пучок котла выполнен из вертикальных дымогарных труб геликоидальной формы для интенсифицикации теплообмена. Топка котла образована газоплотными мембранными экранами с организованной естественной циркуляцией. Под топки футерован огнеупорными материалами. Котлы оборудуют автоматизированными топочными устройствами с паромеханическими форсунками типа KBSA или ротационными типа КВЕ. Основные характеристики котла приведены в табл. 2.

Необходимо отметить особенности технических характеристик современных судовых вспомогательных котлов по сравнению с промышленными. Во-первых, более высокие значения теплового напряжения топочного объема: для судовых котлов $0,8-3,0 \mathrm{MBT} / \mathrm{M}^{3}$, а для промышленных $0,3-0,5 \mathrm{MBT} / \mathrm{M}^{3}$. Это является причиной повышенного уровня температур в топках судовых котлов и, как следствие, большего выброса оксидов азота. Во-вторых, КПД судовых вспомогательных котлов составляет 84-88\%, а температура уходящих газов $360-230^{\circ} \mathrm{C}$ (для промышленных газомазутных котлов такой же паропроизводительности до 20 т/ч, соответственно, 89-91\% и $\left.160-180^{\circ} \mathrm{C}\right)$. Высокая температура уходящих газов снижает эффективность метода рециркуляции для судовых котлов.

Тепловой расчет котла выполнен на основе рекомендаций работ $[3 ; 13]$, а аэродинамический - работ $[1 ; 15]$. Для расчета выхода оксидов азота использованы
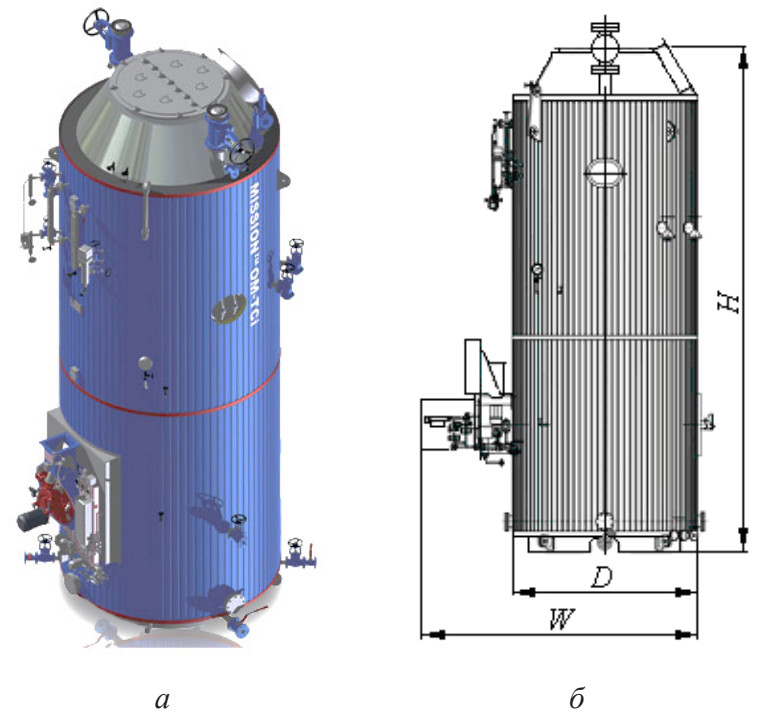

Рис. 2. Котел Ольборг ОМ-ТСі:

$a$ - общий вид; $\sigma$ - габаритные размеры котла

рекомендации работ [10; 12]. При тепловом расчете полагались неизменными тепловые потери от химической неполноты сгорания $0,5 \%$ и наружного охлаждения котла $1,5 \%$, коэффициент избытка воздуха принят как 1,15 . Тепловое напряжение топочного объема принималось 800 кВТ/м³. Топливо малосернистый мазут M40 с низшей теплотой сгорания 39,8 МДж/кг и содержанием азота на рабочую массу $0,4 \%$.

Температура газов на выходе из топки определялась по методике [13], адиабатная и среднеинтегральная температуры в зоне активного горения - по рекомендациям [10]. Адиабатная температура горения, К:

$T_{\text {ar }}=\frac{\beta_{\mathrm{cr}} Q_{i}^{\mathrm{r}}+Q_{\mathrm{rn}}+Q_{\phi}+\alpha_{\mathrm{r}} H_{\mathrm{xB}}^{0}+K_{R} R H_{\mathrm{rp}}}{\beta_{\mathrm{cr}} V_{\mathrm{r}}^{0} c_{\mathrm{r}}+1,0161\left(\alpha_{3 \mathrm{ar}}-\beta_{\mathrm{cr}}\right) V_{\mathrm{B}}^{0} c_{\mathrm{B}}+K_{R} R\left(V_{\mathrm{r}}^{0} c_{\mathrm{r}}+1,0161\left(\alpha_{\mathrm{or} \sigma}-1\right) V_{\mathrm{B}}^{0} c_{\mathrm{B}}\right)}+273$,

где $\beta_{\text {сг }}$-степень выгорания топлива в зоне активного горения (ЗАГ), принимаемая в зависимости от вида сжигаемого топлива; $Q_{i}^{\text {r }}-$ низшая рабочая теплота сгорания топлива, МДж/кг; $Q_{\text {тл }}$ и $Q_{\phi}-$ физическая теплота топлива и форсуночного пара соответственно, МДж/кг; $\alpha_{\mathrm{T}}, \alpha_{\text {заг }}, \alpha_{\text {отб }}-$ коэффициенты избытка воздуха о в топке, зоне активного горения и в месте отбора газов из газохода на рециркуляцию соответственно;

Таблица 2. Характеристики котла Ольборг ОМ-ТСі

\begin{tabular}{|c|c|c|c|c|c|}
\hline $\begin{array}{c}\text { Паропродуктивность, } \\
\text { кг/год }\end{array}$ & $\begin{array}{c}\text { Высота } \\
\text { котла, } \\
H, \text { мм }\end{array}$ & $\begin{array}{c}\text { Диаметр } \\
\text { котла, } \\
D, \mathrm{MM}\end{array}$ & $\begin{array}{c}\text { Ширина } \\
\text { котла, } \\
W, \mathrm{MM}\end{array}$ & $\begin{array}{c}\text { Масса } \\
\text { без воды, } \\
\text { кг }\end{array}$ & $\begin{array}{c}\text { Объем } \\
\text { воды, } \\
\mathbf{m}^{3}\end{array}$ \\
\hline 20000 & 7920 & 3500 & 4930 & 32300 & 15,3 \\
\hline
\end{tabular}


$H_{\text {хв }}^{0}$ и $H_{\text {гр }}-$ энтальпия теоретического количества холодного воздуха и газов рециркуляции, МДж/кг; $K_{R}$ - коэффициент, зависящий от способа ввода газов рециркуляции; $R$ - коэффициент рециркуляции газов; $V_{\mathrm{B}}^{0}$ и $V_{\mathrm{r}}^{0}$ - теоретические объемы воздуха и продуктов сгорания соответственно, $\mathrm{M}^{3} / \kappa г ; c_{\text {в }}$ и $c_{\text {г }}$ - средние объемные изобарные теплоемкости воздуха и продуктов сгорания соответственно, МДж/(м³.К).

Среднеинтегральная температура продуктов сгорания в зоне активного горения, К:

$$
T_{\text {заг }}=T_{\text {ад }}\left(1-\psi_{\text {заг }}\right)^{0,25},
$$

где $T_{\text {ад }}$-адиабатная температура горения топлива, К; $\psi_{\text {заг }}$ средний коэффициент тепловой эффективности поверхностей нагрева, ограничивающих ЗАГ.

Средний коэффициент тепловой эффективности поверхностей нагрева, ограничивающих ЗАГ;

$$
\psi_{\text {заг }}=\frac{\sum\left(\psi_{i} F_{\text {сті }}\right)+\psi^{\prime} F_{\text {верх }}+\psi^{\prime \prime} F_{\text {ниж }}}{F_{\text {ст }}+F_{\text {верх }}+F_{\text {ниж }}},
$$

где $F_{\text {ст }}, F_{\text {верх }}, F_{\text {ниж }}-$ полная поверхность экранированных стен ЗАГ, площадь поперечного сечения топки, ограничивающего ЗАГ сверху и снизу соответственно, м $^{2}$; $F_{\text {сті }}, \psi_{i}$ - площадь участка стены ЗАГ, м², и тепловая эффективность этого участка соответственно; $\psi^{\prime}, \psi^{\prime \prime}-$ коэффициенты, характеризующие отдачу теплоты излучением в выше- и нижерасположенную зону соответственно.

Высота зоны активного горения с учетом ввода газов рециркуляции, м

$$
h_{\text {заг }}=h_{\text {заг }}^{0} \frac{V_{\mathrm{r}}^{R}}{V_{\mathrm{r}}},
$$

где $h_{\text {заг }}^{0}$ - высота зоны активного горения без учета ввода в нее газов рециркуляции и влаги, м; $V_{\text {г }}$ - объем продуктов сгорания, образовавшихся при сжигании 1 кг жидкого топлива в ЗАГ, $\mathrm{M}^{3} / \kappa г ; V_{\mathrm{r}}^{R}$ - объем продуктов сгорания, образовавшихся при сжигании 1 кг жидкого топлива при вводе в ЗАГ газов рециркуляции, $\mathrm{M}^{3} / \kappa г$.

Полная поверхность зоны активного горения, $\mathrm{M}^{2}$,

$$
f_{\text {заг }}=\pi d_{\mathrm{T}} h_{\text {заг }}+2\left(0,25 \pi d_{\mathrm{T}}^{2}\right),
$$

где $d_{\text {т }}$ - диаметр топки, м.
Теплонапряжение зоны активного горения, МВТ/ $/ \mathrm{M}^{2}$,

$$
q_{\text {заг }}=\frac{B_{\mathrm{p}}\left(\beta_{\text {сг }} Q_{i}^{\mathrm{r}}+Q_{\text {тл }}+Q_{\phi}+\alpha_{\mathrm{T}} H_{\text {хв }}^{0}+K_{R} R H_{\text {гр }}\right)}{f_{\text {заг }}},
$$

где $B_{\mathrm{P}}$ - расчетный расход топлива, кг/с.

Отраженный поток в зоне активного горения, МВт/м²,

$$
q_{\text {заг }}^{\text {oтp }}=q_{\text {заг }}\left(1-\psi_{\text {заг }}\right) .
$$

Время пребывания продуктов сгорания в зоне активного горения, с, определяется как

$$
\tau_{\text {заг }}=\frac{0,25 \pi d_{\mathrm{T}}^{2} h_{\text {заг }}}{B_{\mathrm{p}} V_{\mathrm{r}}^{R}\left(T_{\text {заг }} / 273\right)} \xi,
$$

где $\xi$ - коэффициент заполнения топочной камеры восходящими потоками газов (при фронтальном расположении горелок $\xi=0,75)$.

Массовая концентрация оксидов азота (в пересчете на $\mathrm{NO}_{2}$ ) во влажных продуктах сгорания при коэффициенте избытка возду-

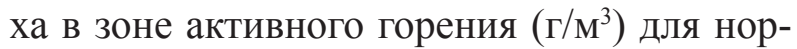
мальных условий $\left(0^{\circ} \mathrm{C}, 101,3\right.$ кПа) определялась по формуле

$$
\mathrm{NO}_{2}=2,05 \cdot 10^{-3} \cdot K_{\Gamma}(a b c) \tau_{3 \mathrm{A \Gamma}}+\Delta \mathrm{NO}_{2}^{\text {ппл }} .
$$

Здесь

$$
\begin{gathered}
a=24,3 \cdot \exp \left(0,19 \frac{T_{\text {ЗАГ }}-1650}{100}\right)-12,3 ; \\
\theta=\exp \left(q_{3 \mathrm{Aг}}^{\text {отр }}\right)-1 ; \\
c=15,1-131,7\left(\alpha_{\text {заг }}-1,09\right)^{4}+72,3\left(\alpha_{\text {заг }}-1,09\right)^{3}+; \\
+73,0\left(\alpha_{\text {заг }}-1,09\right)^{2}+2,8\left(\alpha_{\text {заг }}-1,09\right) \\
K_{\text {Г }}-\text { коэффициент, учитывающий кон- }
\end{gathered}
$$
струкцию горелочного устройства, $\varnothing \mathrm{NO}_{2}^{\text {тпл }}$ член, учитывающий количество топливных оксидов азота при превышении содержания азота в составе мазута $0,3 \%$, рассчитываемый как:

$$
\Delta \mathrm{NO}_{2}^{\text {ппл }}=\frac{650\left(\mathrm{~N}^{r}-0,3\right)}{V_{\text {г }}},
$$

где $V_{\text {г }}$ - объем продуктов сгорания в ЗАГ.

На рис. 3 приведены графики зависимостей температур, характеризующих работу топки: адиабатной, среднеинтегральной в зоне активного горения и на выходе из топки, от коэффициента рециркуляции. Как видно из графиков, рециркуляция дымовых газов в диапазоне 0-20\% приводит к снижению адиабатной температуры в топке 
с 1919 до $1646^{\circ} \mathrm{C}$, среднеинтегральной в зоне активного горения - с 1773 до $1534^{\circ} \mathrm{C}$, а температуры газов на выходе из топки - с 1300 до $1233^{\circ} \mathrm{C}$. Необходимо отметить значительное снижение среднеинтегральной температуры в ЗАГ, определяющей образование оксидов азота.
Температура уходящих из котла газов повышается с 225 до $236^{\circ} \mathrm{C}$, а температура газовоздушной смеси на входе в дутьевой вентилятор - с 30 до $68^{\circ} \mathrm{C}$ (рис. 4). Рост потери теплоты с уходящими газами приводит к уменьшению коэффициента полезного действия котла с 89,2 до 88,7 \% (рис. 5).

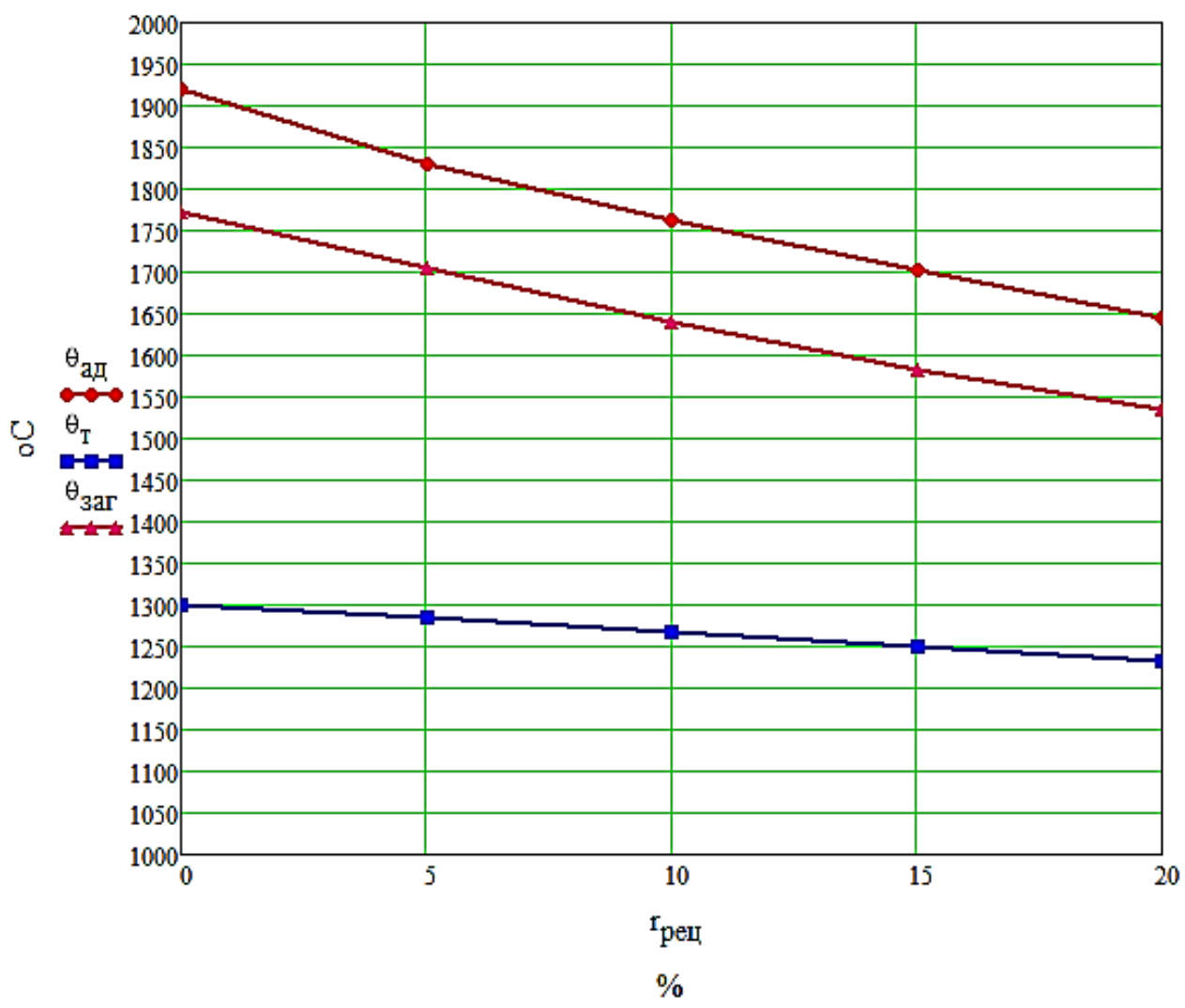

Рис. 3. Зависимость температур, ${ }^{\circ} \mathrm{C}$ : адиабатной $\theta_{\text {ад }}$, на выходе из топки $\theta$ и среднеинтегральной в зоне активного горения $\theta_{\text {заг }}$ от коэффициента рециркуляции, \%.

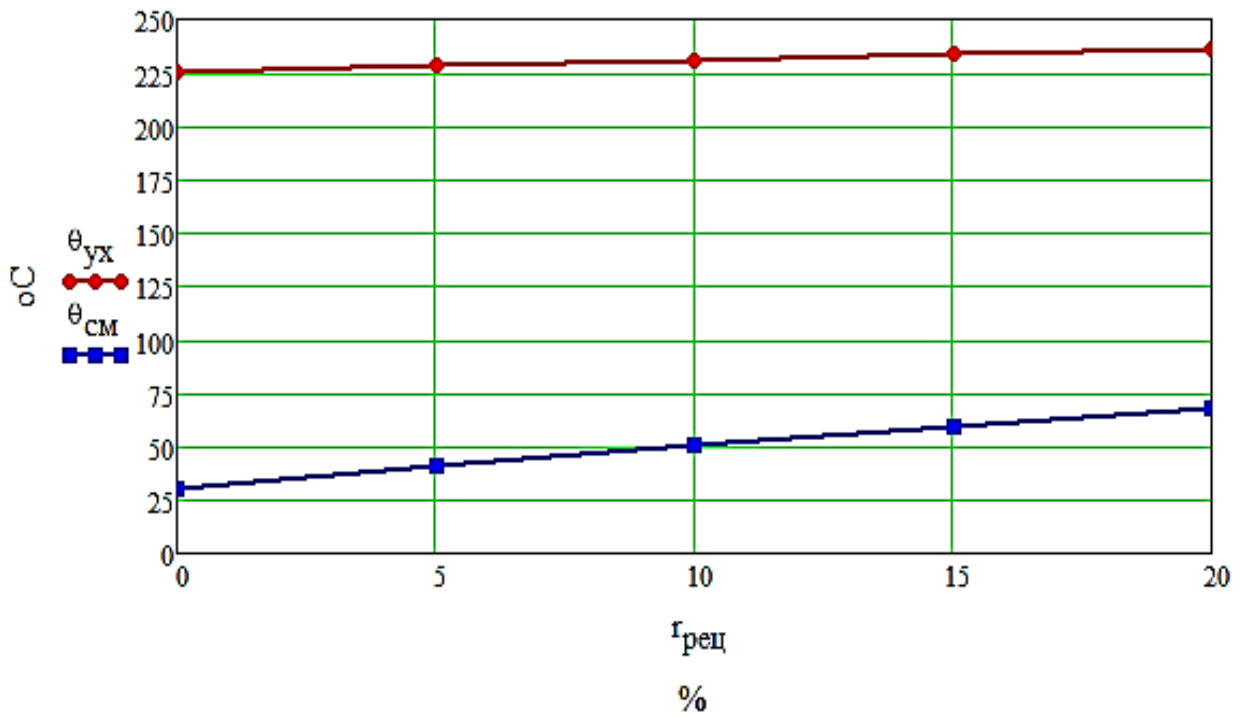

Рис. 4. Зависимость температур, ${ }^{\circ} \mathrm{C}$ : уходящих из котла газов $\theta_{\text {ух }}$, смешения газов и воздуха на входе в дутьевой вентиляор $\theta_{\text {см }}$, от коэффициента рециркуляции, \% 
Тепловая мощность топки уменьшается с 5339 до 4340 кВт, что обусловлено снижением температурного уровня продуктов сгорания (рис. 6). Тепловая мощность конвективного парообразующего пучка возрастает с 8557 до 9477 кВт (рис. 6), что связано с повышением скорости газов с 10,62 до 12,39 м/с. Уменьшение паропроизводительности котла составляет $0,11 \mathrm{~T} / 4$.

Рециркуляция газов и повышение температуры газовоздушной смеси приводит к значительному возрастанию производительности дутьевого вентилятора с 5,22 до 7,12 $\mathrm{m}^{3} / \mathrm{c}$. С увеличением коэффициенета рециркуляции степень снижения выбросов окислов азота замедляется, а степень повышения газового сопротивления котла возрастает (рис. 7). Последнее обусловлено квадратичной зависимостью газового сопротивления котла от скорости газов.

При коэффициенте рециркуляции до $15 \%$ снижение выбросов оксидов азота достигает $44 \%$, а повышение сопротивления газовоздушного тракта котла - 25\%, что приемлемо с экономической точки зрения.

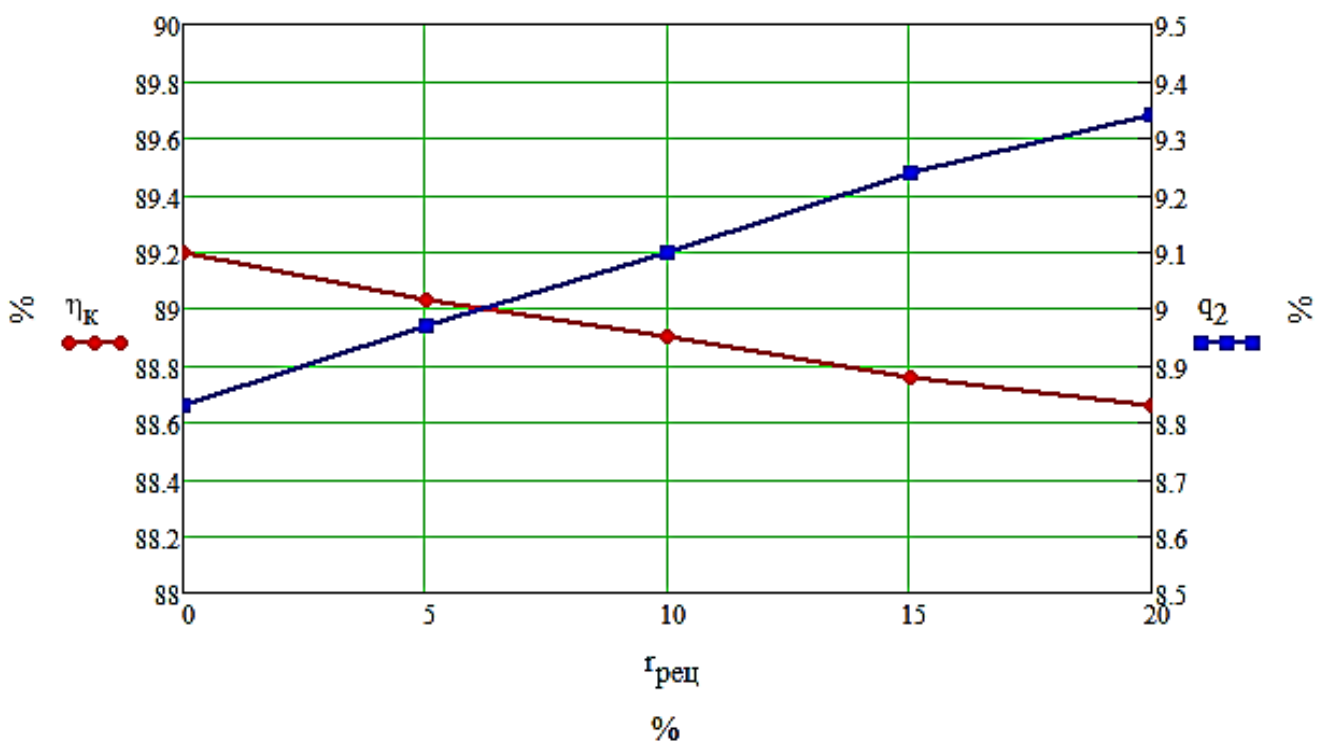

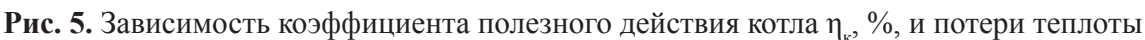
с уходящими газами $q_{2}, \%$, от коэффициента рециркуляции, \%

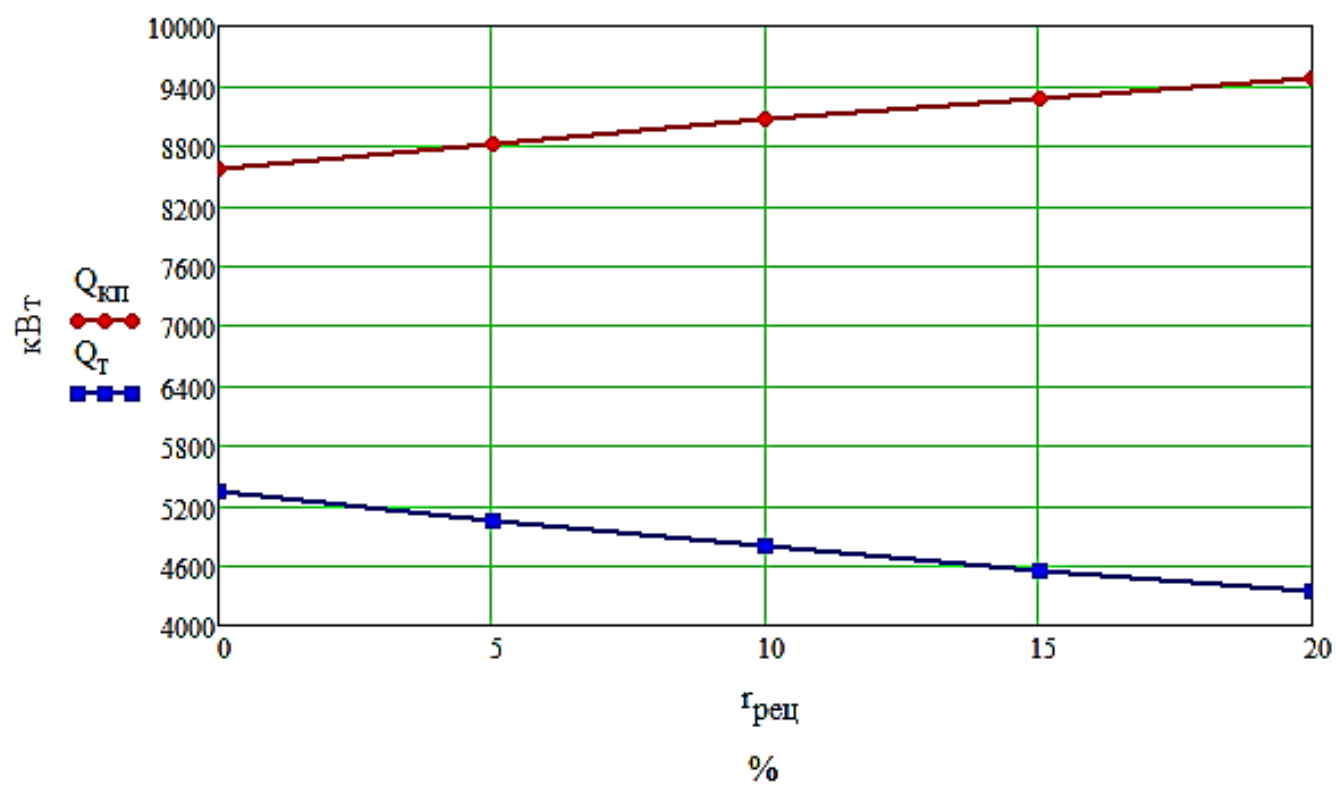

Рис. 6. Зависимость тепловых мощностей, кВт, конвективного пучка $Q_{\text {кп }}$ и топки $Q_{\text {т }}$ от коэффициента рециркуляции, \% 


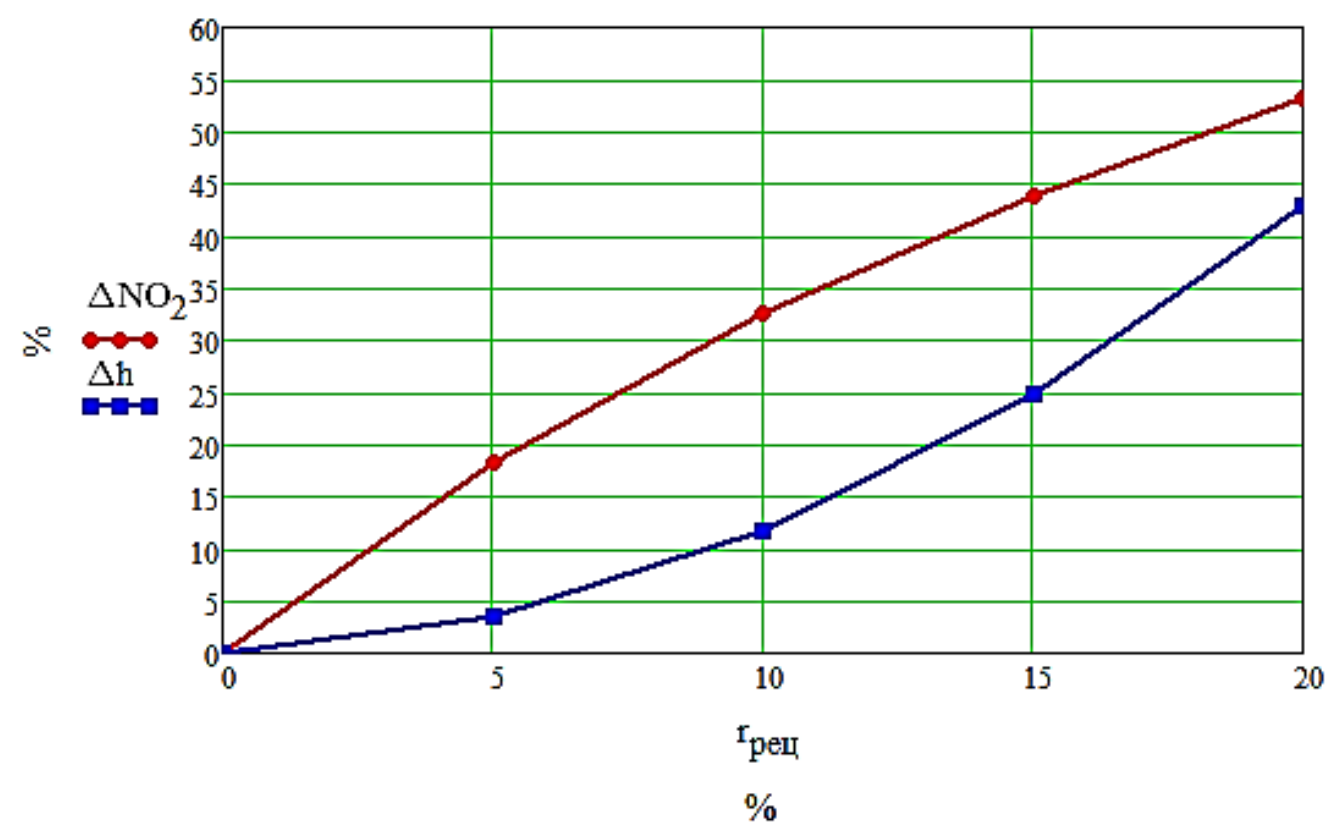

Рис. 7. Снижение выбросов окислов азота $\Delta \mathrm{NO}_{2}, \%$, и повышение газового сопротивления котла $\Delta h$, $\%$, при рециркуляции газов в топку

Обсуждение полученных результатов. Полученные результаты удовлетворительно согласуются с известными данными экспериментальных и теоретических исследований. Так, в работе [6] установлено, что при коэффициенте рециркуляции 15-20\% для промышленного котла ДКВр-4/13 при сжигании газообразного топлива обеспечивается снижение эмиссии оксидов азота на 50-7\% при увеличении давления на прокачку дутьевой смеси на 20-30\%. Большая эффективность рециркуляции обусловлена низкой температурой газов рециркуляции $160^{\circ} \mathrm{C}$. В работе [11] указывается, что при подаче в дутьевой воздух 18-20\% рециркулируемых продуктов сгорания максимальная температура в топочной камере снижается на $150-180^{\circ} \mathrm{C}$, а снижение содержания оксидов азота достигает $39 \%$.

Выводы. Проведен анализ методов снижения выбросов оксидов азота в атмосферу при сжигании углеводородов в котлах. Рекомендован для судовых котлов метод рециркуляции с подачей дымовых газов на вход дутьевого вентилятора, преимущество которой заключается в малозатратности, от- сутствии дополнительного вентилятора, хорошем перемешивании газов рециркуляции с дутьевым воздухом.

Разработана математическая модель для определения влияния рециркуляции дымовых газов на технические и экологические характеристики судового вспомогательного котла.

Рециркуляция дымовых газов в диапазоне 0-20\% приводит к снижению среднеинтегральной температуры в зоне активного горения в диапазоне $1773-1534^{\circ} \mathrm{C}$, коэффициента полезного действия котла - 89,2$88,7 \%$, а его паропроизводительности 5,56-5,53 кг/с. Тепловая мощность топки уменьшается с 5339 до 4340 кВт, а конвективного парообразующего пучка - возрастает с 8557 до 9477 кВт.

Рекомендованное значение коэффициента рециркуляции находится в диапазоне 10-15\%. При этом обеспечивается снижение эмиссии оксидов азота на 33-44\% при увеличении давления на прокачку дутьевой смеси на $12-25 \%$.

Следующим этапом научного исследования является экспериментальная проверка полученных результатов. 


\section{Список литературы}

[1] Аэродинамический расчет котельных установок (Нормативный метод). Ленинград : «Энергия», 1977. $255 \mathrm{c}$.

[2] Єпіфанов О.А. Тепловий розрахунок котельних агрегатів малої потужності : навчальний посібник. Миколаїв : НУК, 2004. 152 с.

[3] Єпіфанов О.А. Конструкції суднових котлів. Навчальний посібник. Миколаїв : НУК, 2016. 198 с.

[4] Кабишов С.М. Анализ эффективности технологических методов снижения выбросов $\mathrm{NO}_{x}$ при сжигании углеводородного топлива в теплоэнергетических установках. Энергетика. Известия высших учебных заведений и энергетических объединений СНГ. 2013. № 2. С. 48-53.

[5] Каныгин А.В. О современных методах снижения образования оксидов азота при сжигании газа в котлах малой и средней мощности. Промышленная теплотехника. 2013. № 2. С. 79-86.

[6] Кобзарь С.Г., Халатов А.А. Снижение выбросов оксидов азота в газовых котлах методом рециркуляции дымовых газов. Промышиленная теплотехника. 2009. Т. 31. № 4. С. 5-11.

[7] Михайлов А.Г., Батраков П.А., Теребилов С.В. Разработка теоретически основ снижения образования оксидов азота в топках газотрубных котлов. Научный журнал КубГАУ. 2013. № 90 (06).

[8] Парчевский В.М. Управление выбросами оксидов азота на ТЭС рециркуляцией дымовых газов : дис. ... канд. техн. наук : 05.13.06. Москва, 2010. 199 с.

[9] Приложение VI к МАРПОЛ 73/78. Правила предотвращения загрязнения атмосферы с судов. URL: http://www.morkniga.ru.

[10] РД 153-34.02.304-2003. (2003). Методические указания по расчету выбросов оксидов азота с дымовыми газами котлов тепловых электростанций. Москва : ОАО «ВТИ». 42 с.

[11] Сигал И.Я. Особенности влияния рециркуляции продуктов сгорания на образование оксидов азота в котлах при сжигании природного газа. Энерготехнология и ресурсосбережение. 2018. № 4. С. 62-66.

[12] Таймаров М.А., Чикляев Д.Е. Образование термических окислов азота при сжигании газа. Вестник Казанского технол. ун-та. 2013. Т. 16. № 23. С. 73-75.

[13] Тепловой расчет котлов (нормативный метод). 3-е изд., переработанное и дополненное / РАО ЕС России, ВТИ, НПО ЦКТИ; [редкол.: А.А. Абрютин и др.]. Санкт-Петербург : Изд-во НПО ЦКТИ, 1998. $256 \mathrm{c}$.

[14] Тимофеев О.Я., Вальдман Н.А., Крыжевич М.И. Особенности внедрения новых требований к экологической безопасности судов и морских установок в северных морях и на арктическом шельфе. Арктика: экология и экономика. 2014. № 3(15). С. 79-85.

[15] Хряпченков А.С. Судовые вспомогательные и утилизационные котлы : учебное пособие. 2-е изд., перераб. и доп. Ленинград : Судостроение, 1988. 296 с.

[16] Федоренко В.М., Залетов В.М., Руденко В.И., Беляев И.Г. Эксплуатация судовых котельных установок : учебник для высш. инж. мор. училищ. Москва : Транспорт, 1991. 272 с.

[17] Alfa Laval Aalborg Industries. URL: http://www.aalborg-industries.com/marine boilers.

[18] SAACKE GmbH. URL: http://www.saacke.com/products/marine-boilers.

[19] Ganapathy V. Steam Generators and Waste Heat Boilers: For Process and Plant Engineers. (C) 2015 by Taylor \& Francis Group, LLC. 495 p.

[20]. Reduction of $\mathrm{SO}_{2}, \mathrm{NO}_{\mathrm{x}}$ and Particulate Matter from Ships with Diesel Engines. (2014). Environmental Project. no.1510. 114 p. URL: https://www2.mst.dk/Udgiv/publications/2014/03/978-87-93026-57-5.pdf.

(c) Епифанов А. А., Дымо В. В., Пацурковский Р. А., Язловецкий А. В. Дата надходження статті до редакції: 30.10 .2020 Дата затвердження статті до друку: 27.11.2020 